\title{
STRUCTURE OF RELATIONS BETWEEN THE FREQUENCY OF MICRONUCLEI IN PERIPHERAL BLOOD LYMPHOCYTES AND AGE, GENDER, SMOKING HABITS AND SOCIO-DEMOGRAPHIC FACTORS IN SOUTH-EAST REGION OF SERBIA
}

\author{
Andjelka Hedrih $^{1}$, Stevo Najman ${ }^{2}$, Vladimir Hedrih ${ }^{3}$, Olivera Milošević-Djordjevićc ${ }^{4}$ \\ ${ }^{1}$ Department of Mechanics, Mathematical Institute of Serbian Academy of Sciences and Arts, Belgrade, Serbia \\ ${ }^{2}$ Department of Biology and Human Genetics, Faculty of Medicine, University of Niš, Niš, Serbia \\ ${ }^{3}$ Department of Psychology, Faculty of Philosophy, University of Niš, Niš, Serbia \\ ${ }^{4}$ Department of Genetics, Faculty of Science, University of Kragujevac, Serbia, Kragujevac, Serbia
}

\begin{abstract}
Frequency of micronuclei $(M N)$ in peripheral blood lymphocytes is a measure of genotoxicity and spontaneous chromosomal instability with many modifying factors. The aim of this work was to examine the relation between results of micronucleus test and set of socio-demographic parameters in healthy population in south-east Serbia using structure equation approach. Cytokinesis-block (CB) technique was used for analysis of $M N$ frequency in peripheral blood lymphocytes on 133 healthy volunteers of various ages. Socio-demographic data was collected through a questionnaire. The mean frequency of MN gradually rose with age from $0.56 \pm 0.71$ in new-borns to $5.48 \pm 3.65$ in the 61-80 years age group (AG), with a decrease in the 81-92 years AG. MN frequency was positively correlated with age, altitude of birth place, altitude of place of residence, nuclear buds and nucleoplasmatic bridges, and negatively with education level and smoking habits. Linear structural model revealed age to be related to all of the examined variables, and indicates probable existence of another factor, independent of age, influencing all of these except nuclear buds. It can be concluded that the frequency of micronuclei is influenced by age and factor/s resembling socioeconomic status or lifestyle and this influence is independent of age.
\end{abstract}

Key words: micronuclei, age, gender, education level, socio-demographic factors.

\section{Introduction}

Micronuclei $(\mathrm{MN})$ are chromatin particles that are created as a result of chromosomal break or elimination of whole chromosomes as a consequence of mitotic spindle damage and a biomarker of genotoxic events [1-3] (and chromosomal instability [4]. Frequency of MN in peripheral blood lymphocytes of healthy subjects is environment specific [5] and increases with chronological age [6-13]. Specific increase of MN frequency with age was found in mice [14]. The origins of MN formation are reviewed recently $[4,15]$.

According to [15] factors that affect MN frequency in healthy subjects are: type of cell line, gender, age, genotype, smoking, species and diet. For gender, results are conflicting: some studies report higher $\mathrm{MN}$ in women than in men $[8,10,12,16-19]$ but some studies report no gender effect on MN frequency [13]. MN frequency increases with age. Mayer et al. (1989) report age and gender differences in DNA repairing mecha-

Correspondence to: Andjelka Hedrih, Ph.D.

Department of Mechanics, Mathematical Institute of Serbian

Academy of Sciences and Arts, Belgrade, Serbia, 36 Kneza Mihaila,

11000 Belgrade, Serbia

Phone: +381648013320

E-mail: handjelka@turing.mi.sanu.ac.rs

Received January $2^{\text {nd }}, 2018$, Accepted June $28^{\text {th }}, 2018$ nisms: "Decline in double-strand DNA break damage induction occurs more rapidly (by a factor of ca. 2) in women than in men" [20].

Results on the effects of smoking are also conflicting with some studies reporting no effect of smoking on MN frequency [10,13]. Kažimirova et al. (2006) did not find significant differences in micronucleus frequency between vegetarians and non-vegetarians across different age groups [17]. Regarding the relation between occupational exposure to electromagnetic fields and incidence of micronuclei, Lakshmi et al. (2010) point out that overall DNA damage and incidence of micronuclei showed no significant differences between the subjects with occupational exposure to electromagnetic fields emitted from video display terminals and control group. Only long-term users of video display terminals (more than 10 years) showed higher induction of DNA damage and increased frequency of micronuclei and micro nucleated cells [21].

In studies where no correlation was found between $\mathrm{MN}$ and gender, one explanation could be that although statistics show that women live longer than men, women's health conditions after the age of 80 are worse than those of men of equal age [22,23].

Many studies explore different social, biochemical, lifestyle and genetic factors that may influence health 
status especially in people over 70 years of age [22,24-28]. A decline in T cell function during aging is thought to contribute to reduced response to infection and vaccination and an increase in autoimmunity [29].

Steves et al. (2012) discussed why DNA sequenceidentical twins might age differently [27]. Discussing epigenetic and early developmental hypotheses of ageing, Steves et al. (2012) suggest that longevity and lifespan seem not to be so heritable [27]. Some environmental factors like exercise, smoking and diet can strongly influence aging [27]. Other authors [30] found that long-lived parents tend to have children with longer life than their age peers.

Different organs age at different speeds [27,31] probably due to different antioxidant response and DNA repair [32,33)]. Liochev (2013) suggests that reactive oxidative species such as hydrogen peroxide and superoxide are not just causative agents of aging but may also be agents that in small concentrations increase the life span by increasing the upregulation of proteins that act as protective factors in oxidative stress thus providing adaptation (33].

The goal of the current study was to examine the relation between results of micronucleus test and set of socio-demographic parameters: personal factors such as gender, education level and microclimate factors of the environment a person lives in indicated by the altitude of birthplace and of current place of residence using structure equation approach. A working hypothesis was that people who lived in places with higher altitude, non-smokers and people with higher education will have lower frequency of $\mathrm{MN}$ due to life style and reduced risk factors for increased $\mathrm{MN}$ frequency.

\section{Materials and Methods}

\section{Sample}

One hundred thirty three healthy volunteers of various age (from new-borns - 0 years of age to 92 years) participated in the study. Participants were divided into 5 groups as follows: age group 1 - new-borns (29 participants of which 13 were females (f) and 16 were males (m); mean age was 0 years, second age group from 21 40 years (30 participants- of which 16 were $\mathrm{f}$ and 14 were $\mathrm{m}$, mean age $25.1 \pm 4.56$ ); third age group from 41 60 years (29 participants of which 16 were $f$ and 13 were $\mathrm{m}$, mean age $47.47 \pm 5.02$ ); fourth age group from 61-80 years (26 participants of which 18 were $\mathrm{f}$ and 8 were $\mathrm{m}$; mean age $71.88 \pm 4.55)$ and fifth age group -81 years and above (19 participants-of which 13 were $f$ and 6 were m; mean age $85.18 \pm 3.33$ ). Guided by the experience from previous studies (9) we have taken 5 different age groups (for population from 0-100 years) were each age group covers the period of 20 years.

\section{Sampling procedure}

From each participant $2 \mathrm{ml}$ of blood was taken from elbow vein (v. cubitalis). From new-borns, blood was taken from umbilical cord after birth at the Clinic for Gynaecology and Obstetrics, Clinical Centre Nis, Serbia. New-borns from healthy mothers that fulfilled the above-mentioned criteria, without gestational diabetes [34], natural conception, regular pregnancy, without infections during pregnancy or consumption of antibiotics during pregnancy, term labour with regular duration, vaginal delivery, and Apgar score 9 or 10, were included in the study. New-borns whose mothers had prolonged labour or caesarean section were excluded from the study. New-borns that had elevated levels of bilirubin or $\mathrm{C}$ reactive protein within three days after birth were excluded from the study.

\section{Variables and participants}

Spontaneous chromosomal aberration was assessed by using the micronucleus test. Volunteers were recruited during regular control examinations in: the Health Centre Niš, Student Policlinic Nis, Gerontological Centre Niš, Clinic for Gynaecology and Obstetrics, Clinical Centre Nis, Brestovac medical station, and Health centre Bela Palanka, Serbia.

The study was approved by the Ethical committee of the Faculty of Medicine, University of Nis, Serbia (019068-7) and the Ethical committee of Clinical Centre Niš, Serbia (2280/11). All participants gave informed consent.

Participants were screened for health status that was assessed on the basis of biochemical (general blood count, sedimentation, blood sugar) and anamnesis data in order to exclude participants with health conditions known to influence the frequency of micronuclei. Exclusion criteria used were absence of diabetes, chemo-or radiotherapy at the moment and in the past, tumour/s, operations of tumour of any kind in the past, exposure to chemical and physical mutagens, alcohol and/or drugs abuse (absolute alcohol non-users, and occasional alcohol use, absolute narcotics and related substances non-users), HCV (Hepatitis C virus) and/or HBV (Hepatitis $\mathrm{B}$ virus) infection, dementia, heart attack survivors. Participants who passed exclusion criteria were considered healthy and included in the study. For collecting demographic and anamnestic data of interest (range of altitude of birthplace and place of residence, smoking habits, education level) a short questionnaire was used. Range of altitude of birthplace $(300 \pm 184.14 \mathrm{~m}$ above sea level, $\min 77 \mathrm{~m}, \max 1310 \mathrm{~m}$ above sea level) and current place of residence $(237.59 \pm 90.34 \mathrm{~m} \mathrm{~min}$ $194 \mathrm{~m}$, max $574 \mathrm{~m}$ above sea level) were used as a holistic indicator of the environment a person lives in. In the part of Serbia where the study was conducted, places of higher altitude (above $255 \mathrm{~m}$ above sea level) tend to have colder climate with more snow and to be more sparsely populated and less developed compared to 
places of lower altitude (city in the valley at $194 \mathrm{~m}$ above sea level). Also, a number of studies have indicated that biological processes can be affected by altitude [35-38] (e.g. haemoglobin affinity for oxygen). Altitude of birthplace and of current place of residence were derived by looking up the data for the place participants indicated living or being born in and expressed in meters above sea level.

Analysis of MN frequency in peripherals blood lymphocytes was conducted by cytokinesis-block technique-modification according to the Fenech and Morley $[4,5,9]$.

NDI was calculated according to the method of Eastmond and Tucker using http://www.nature.com/ nprot/journal/v2/n5/full/nprot.2007.77.html - B107 the formula:

$$
N D I=\frac{M_{1}+2 M_{2}+3 M_{3}+4 M_{4}}{500}[39]
$$

where M1-M4 represents the number of cells with 1-4 nuclei.

\section{Anamnestic/sociodemographic data}

Smoking status was determined by asking participants if they were smokers (3), former smokers (2) or nonsmokers (1). They were also asked to specify the number of cigarettes they smoke daily ( 0 for former and non-smokers). Age was registered as number of years since birth at the time the study was conducted ( 0 for new-borns). Education level was registered as the highest completed level of education (education level of mothers was registered for the new-borns).

\section{Cytokinesis block micronucleus test (MN) protocol}

The culture of peripheral blood lymphocytes was set up according to the modified Fenech and Morley method [9]. After $44 \mathrm{~h}$ of incubation at $37^{\circ} \mathrm{C}$ (Celsius degree) in fully-supplemented medium for culture of peripheral blood lymphocytes for cytogenetic studies (PB-MAX karyotyping medium, Life Technologies 12557), cytochalasin B in final concentration of $4 \mu \mathrm{g} / \mathrm{ml}$ was added. After that, cell cultures were incubated for another 24 hrs. Preparation was done in $0.56 \% \mathrm{KCl}$ hypotonic solution. Fixation of material was conducted by fixative that consisted of glacial acetic acid and methanol $(1: 3 \mathrm{v} / \mathrm{v})$, according to the protocol: fixative was mixed with prepared sample and incubated for $15 \mathrm{~min}$. After that, sample was centrifuged for $12 \mathrm{~min}$ on $1700 \mathrm{r} / \mathrm{min}$, than supernatant was discarded. This fixation procedure was repeated 3 times. Preparations were stained with $2 \%$ Giemsa solution. The analysis of $\mathrm{MN}$ as well as nucleoplasmatic bridges (NPB), nuclear buds were done on 1000 binucleated cells per each of 133 tested individuals. Nuclear division index (NDI) was calculated for each individual. The culture of peripheral blood lymphocytes from participants over 80 years of age was set up in double culture.

\section{Statistics}

Average value and standard deviation of micronuclei frequency per 1000 binuclear cells were calculated for each age group as well as correlations between the results of MN test and other variables included in the study. To further examine the nature of relationship between the examined variables a linear regression analysis was conducted. Finally, a linear structural model of the examined relationships was created using asymptotically distribution-free discrepancy estimation method as implemented by AMOS software.

\section{Results}

Average value and SD of MN and NDI for each age group are presented in Table 1. Distributions of NDI, $\mathrm{BN}$ cells with 1,2 and $3 \mathrm{MN}$ across age groups are shown in Figure 1. MN1 and MN2 increased significantly with age (Spearman's correlation $\mathrm{r}=0.650$, $\mathrm{p}<$ $0.0001 ; \mathrm{r}=0.289, \mathrm{p}<0.001$ respectively). NDI did not show significant differences across age groups. Correlations between the results of micronucleus test and other variables included in the study were calculated. Results are shown in Table 2. To test if there are gender differences in NDI, BN cells with 1, 2 and $3 \mathrm{MN}$ in the same age group the analysis of variance was performed. There were no significant differences between genders in tested variables, and this finding persisted throughout the age groups as can be seen in Table 3. Significant negative correlation was found between NDI and nucleoplasmatic bridges $(\mathrm{NPB})(\mathrm{r}=-0.183, \mathrm{p}<0.05)$

Table 1 Mean micronuclei frequencies and nuclear division indices in studied age groups.

\begin{tabular}{llrcc}
\hline & Age range in years & $\mathrm{n}$ & $\begin{array}{c}\mathrm{MN} \\
(\mathrm{mean} \pm \mathrm{SD})\end{array}$ & $\begin{array}{c}\text { NDI } \\
(\mathrm{mean} \pm \mathrm{SD})\end{array}$ \\
\hline 1 & 0 & 29 & $0.56 \pm 0.71$ & $1.52 \pm 0.30$ \\
2 & $21-40$ & 30 & $0.82 \pm 0.78$ & $1.72 \pm 0.26$ \\
3 & $41-60$ & 29 & $1.26 \pm 1.48$ & $1.68 \pm 0.35$ \\
4 & $61-80$ & 26 & $5.48 \pm 3.65$ & $1.55 \pm 0.24$ \\
5 & $81-92$ & 19 & $4.48 \pm 2.69$ & $1.62 \pm 0.34$ \\
\hline & Total mean \pm S.D. & 133 & $2.36 \pm 2.92$ & $1.62 \pm 0.30$ \\
\hline
\end{tabular}

Legend: $\mathrm{n}-$ number of participants in a group. $\mathrm{MN}-$ micronuclei frequency per 1000 binuclear cells. NDI - nuclear division index. Means and standard deviations for each of the five age groups and for the total sample are presented.

Correlations between gender and micronuclei frequency were not statistically significant. In the current sample $66.9 \%$ were non-smokers, $40.6 \%$ of which females, $7.5 \%$ former smokers, $25.6 \%$ smokers, $15 \%$ of which females. Mean value of number of cigarettes/day and time period of smoking in years rise in the third age group (Fig. 2). New-borns were excluded from analysis of smoking status. Distributions of smoking status across age groups for females and males are presented in Figure 3. 


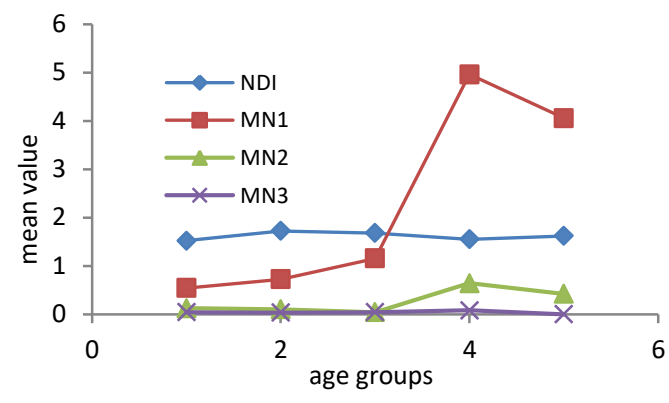

Fig. 1 Distribution of NDI, MN1, MN2, MN3 across age groups. Age groups (1-5) are presented on the horizontal axis. On vertical axis are mean values of NDI, MN1, MN2 and MN3 in each age group.

Table 2 Correlations of micronuclei frequency and studied socio-demographic factors

\begin{tabular}{|c|c|c|}
\hline tested variables & $\begin{array}{l}\text { Spearman } \\
\text { correlation } \\
\text { coefficient }\end{array}$ & $\mathrm{p}$ \\
\hline Age (in years) & 0.61 & $<0.001$ \\
\hline $\begin{array}{l}\text { Altitude of birth place } \\
\text { (in meters above sea level) }\end{array}$ & 0.34 & $<0.001$ \\
\hline $\begin{array}{l}\text { Altitude of current place of residence } \\
\text { (in meters above sea level) }\end{array}$ & 0.45 & $<0.001$ \\
\hline $\begin{array}{l}\text { Nuclear buds (number of cells with } \\
\text { nuclear buds per } 1000 \text { binuclear cells) }\end{array}$ & 0.34 & $<0.001$ \\
\hline $\begin{array}{l}\text { Nucleoplasmatic bridges } \\
\text { (number of cells with nucleoplasmatic } \\
\text { bridges per } 1000 \text { binuclear cells) }\end{array}$ & 0.18 & $<0.05$ \\
\hline Education level & -0.39 & $<0.001$ \\
\hline $\begin{array}{l}\text { Smoking } \\
\text { (1-Non-smoker, 2-former smoker, 3-smoker) }\end{array}$ & -0.28 & $<0.05$ \\
\hline Number of smoked cigarettes per day & -0.25 & $<0.05$ \\
\hline
\end{tabular}

Table 3 Effect of gender and age interaction with NDI, MN1, MN2 and MN3

\begin{tabular}{ccccc}
\hline Source & $\begin{array}{c}\text { Dependent } \\
\text { Variable }\end{array}$ & df & F & Sig. \\
Gender X Age & & & & \\
\hline & NDI & 4 & 0.32 & 0.87 \\
& MN1 & 4 & 0.50 & 0.74 \\
& MN2 & 4 & 0.37 & 0.83 \\
MN3 & 4 & 1.26 & 0.29 \\
\hline
\end{tabular}

Legend: NDI - nuclear division index. MN1 - number of cells with one micronucleus per 1000 binuclear cells. MN2 - number of cells with two micronuclei per 1000 binuclear cells. MN3 number of cells with three micronuclei per 1000 binuclear cells.

Older participants from the current sample tended to be born and live at higher altitude (10.5\% of participants in the fifth age group live at $574 \mathrm{~m} 36.8 \%$ at $395 \mathrm{~m}$ and $47.4 \%$ at $194 \mathrm{~m}$ above sea level; $53.8 \%$ of participants in the fourth age group live at altitude of $395 \mathrm{~m}, 26.9 \%$ at altitude of $194 \mathrm{~m}$ above sea level, $58.6 \%$ of participants in the third age group live at altitude of $200 \mathrm{~m} 82.8 \%$ of participants in the first age group and $100 \%$ of participants in the second age group live at $194 \mathrm{~m}$ above sea level), to be less educated (18.9\% of participants did not finished primary school of which $6.8 \%$ and $6.1 \%$ belong to the fourth and fifth age group respectively; $12.9 \%$ finished primary school of which 5.3\% and 3.8\% belong to the fourth and fifth age group respectively; $23.5 \%$ have secondary school of which $9.1 \%$ belong to the third age group; $3.8 \%$ have college of which $1.5 \%$ belong to the fourth age group; $39.4 \%$ have faculty of which $22.7 \%$ belong to the second age group; $1.5 \%$ have $\mathrm{PhD}$ and they all belong to third age group), nonsmoking and had a larger percentage of nuclear buds (NB) and nucleoplasmatic bridges, as can be seen in Fig. 4. All these correlations were statistically significant, and are presented in Table 2.

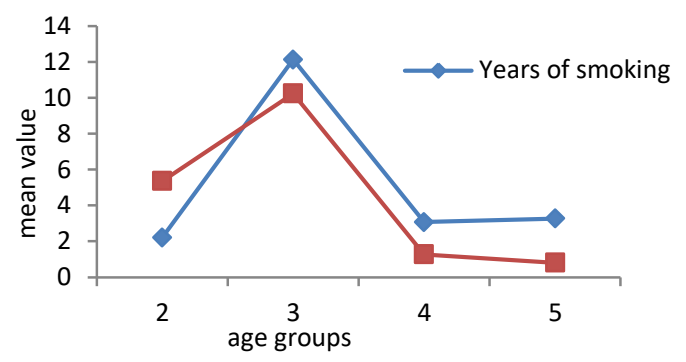

Fig. 2 Mean value of number of cigarettes /day and time period of smoking in years across different age groups. Age group 1, new-borns; Age group 2, 21-40 years; Age group 3, 41-60 years; Age group 4, 61-80 years; Age group 5, 81 years and above.

Taking into account the obtained results, further analyses were conducted in order to examine possible relationship between predictors that would shed additional light on nature of the obtained results. These investigations demonstrated a systematic relationship between age and the number of other included variables. To further examine the nature of relationship between the examined variables a linear regression analysis was conducted. Results show that, when age is included in the model, direct effects of a number of other predictors become statistically insignificant. Finally, a linear structural model of the examined relationships was created using asymptotically distribution-free discrepancy estimation method as implemented by AMOS software.

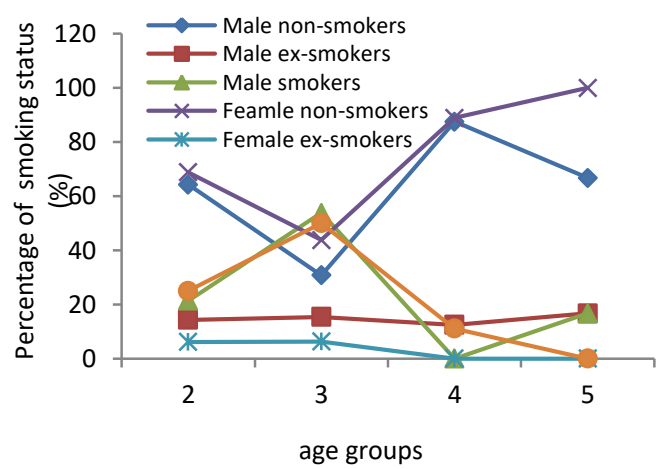

Fig. 3 Distributions of smoking status across age groups for females and males Age group 1, new-borns; Age group 2, 21-40 years; Age group 3, 41-60 years; Age group 4, 61-80 years; Age group 5, 81 years and above. 

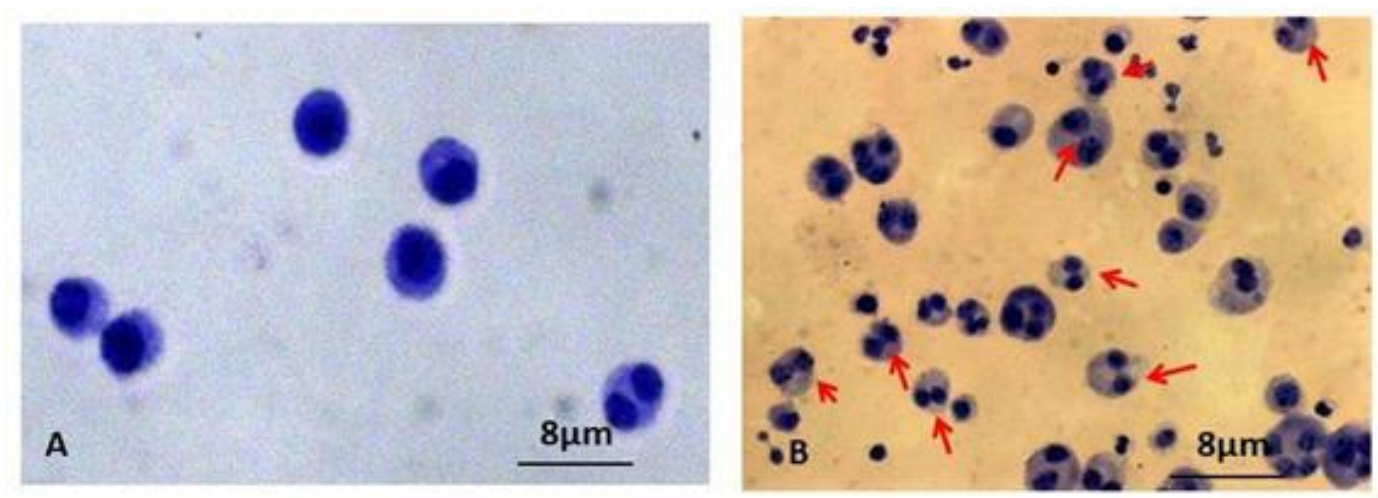

Fig. 4 MN of peripheral blood lymphocytes: A. from new-born baby-boy. B. from man of 90 years of age. $\mathrm{NC}$ bridges are visible on $\mathrm{B}$.

This model is presented in Figure 5 and Table 4. The model has good fit parameters: GFI $=0.988$, AGFI $=$ 0.972, CFI $=0.985$, NFI=0.899, RMSEA = 0.034, ChiSquare Statistic $=17.129$, Chi-Square $\mathrm{p}=0.311$ ), Degrees of freedom $=15$. The model depicts age influencing $\mathrm{MN}$, altitude of birth and living place, smoking habits, nucleoplasmatic bridges, and nuclear buds. It also shows that correlations of altitude of birthplace and of current place of residence, smoking habits, education level, nucleoplasmatic bridges, nuclear buds with results of micronucleus test, are in fact due to all of them being influenced by age. Results suggest the existence of another factor, independent of age, that influences all these variables expect nuclear buds. For the purposes of proposing and testing a structural model, regression weight of the proposed unknown factor with education level has been constrained to 1 .

Table 4 Structural model parameter estimates

\begin{tabular}{|c|c|c|c|c|}
\hline To & From & $\begin{array}{c}\text { Regression } \\
\text { estimate }\end{array}$ & $\begin{array}{l}\text { Standard } \\
\text { Error }\end{array}$ & $\begin{array}{c}\text { Statistical } \\
\text { significance }\end{array}$ \\
\hline Micronuclei & Age & 0.505 & 0.049 & $\mathrm{p}<0.001$ \\
\hline Birthplace altitude & Age & 0.436 & 0.070 & $\mathrm{p}<0.001$ \\
\hline $\begin{array}{l}\text { Altitude of the place } \\
\text { person lives in }\end{array}$ & Age & 0.418 & 0.075 & $\mathrm{p}<0.001$ \\
\hline Education & Age & -0.374 & 0.079 & $\mathrm{p}<0 . .001$ \\
\hline Micronuclei & $\mathrm{X}$ & -0.845 & 0.283 & 0.003 \\
\hline Education & $\mathrm{X}$ & 1.000 & & \\
\hline Smoking & $\mathrm{X}$ & 1.122 & 0.340 & $\mathrm{p}<0.001$ \\
\hline $\begin{array}{l}\text { Nucleoplasmic } \\
\text { bridges }\end{array}$ & $\mathrm{X}$ & -.0992 & 0.420 & 0.018 \\
\hline Smoking & Age & -0.204 & 0.078 & 0.009 \\
\hline $\begin{array}{l}\text { Nucleoplasmic } \\
\text { bridges }\end{array}$ & Age & 0.130 & 0.057 & 0.022 \\
\hline $\begin{array}{l}\text { Elevation of the } \\
\text { place person lives in }\end{array}$ & $\mathrm{X}$ & -1.916 & 0.461 & $\mathrm{p}<0.001$ \\
\hline Birthplace elevation & $\mathrm{X}$ & -2.028 & 0.474 & $\mathrm{p}<0.001$ \\
\hline Nuclear buds & Age & 0.249 & .0066 & $\mathrm{p}<0.001$ \\
\hline
\end{tabular}

\section{Discussion}

The results presented here showed that mean $\mathrm{MN}$ frequency does not increase linearly with age; in the 5th age group (participants over 80 years of age) it decreases, compared to the 4th age group. A probable explanation for this finding is that $80+$ year olds that also pass the exclusion criteria to be included in the study are a group of individuals with much better health compared to an average person of this age. As the age of 80 is well above the mean life expectancy for the population of Serbia (which is around 75), it can be argued that $80+$ year olds that lived to this age have unique genetic background that allowed them to live and stay healthy up to the age they have. The MN frequency is just one of the indicators of this. It is possible that in this age group, spontaneous chromosomal instability is stabilised at the lower level. In support of this hypothesis are results of the study [40] which reported no correlation between telomeres shortening and age in 79 years old subjects. Harrisa et al. (2012) found that telomeres shortening in people of 70 years of age did not correlate with their socio-economic status [26]. Telomere shortening is connected with oxidative stress and it is possible that the level of oxidative stress is lower in this age group [40]. Beside long-life experience and adaptation to stressful situations [41], lower level of stress in this age group could be explained by reduced caloric intake and gradual decrease in proliferative cell capacities $[9,43]$ suggesting that mechanisms leading to the formation of micronuclei containing sex chromosomes differ with age. They also report the nonlinear increase of $\mathrm{MN}$ frequency with age-after 70 years of age it decreases [42]. 


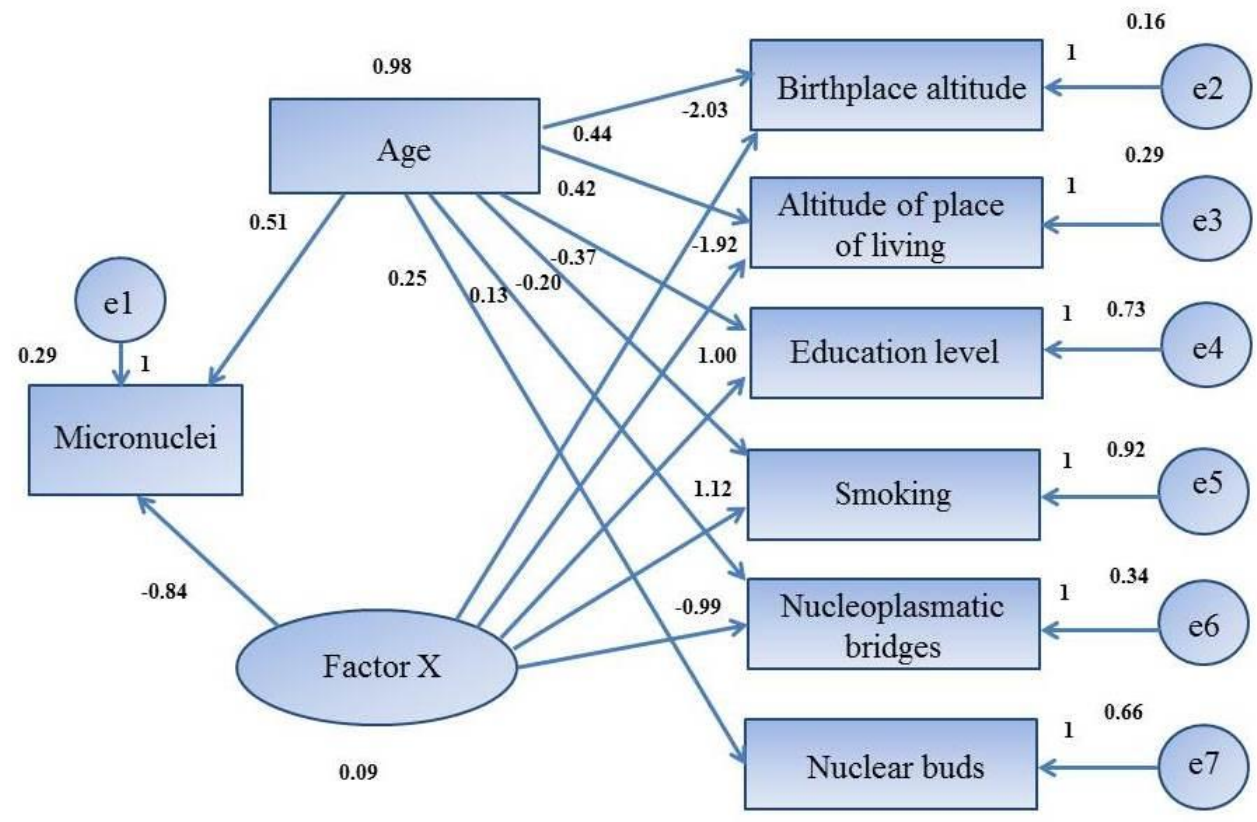

Fig. 5 Structure linear model relationship between age and unknown Factor $X$ and altitude of birth and living place, education level, smoking habits, nucleoplasmatic bridges, nuclear buds and micronuclei. Numbers represent structural coefficients for each relation.

Cigarette smoking is an important and established risk factor in many age-related diseases, and is associated with increased cumulative and systemic oxidative stress and inflammation like increased circulating blood leucocytes [43] and have been linked to poorer health outcomes and associated with shorter telomeres (Valdes et al. by [26]. Negative correlations between MN frequency and number of smoked cigarettes/day were obtained. Some recent studies reported smoking having no effect on $\mathrm{MN}$ frequency [10,13], while other reported positive correlations between MN frequency and smoking [11,12]. Smoking more than 30 cigarettes/day increased the MN frequency [8]. Our results showed negative correlation between education level and MN frequency which is in accordance with results of study in Poland (Szklarska and Rogucka 2001), they found relation between education level and biological age: better-educated men were biologically younger than their poorer educated peers [44]. Linear structural model shows that age is the factor explaining all of the above mentioned variables, although we know that the linear relationship does not hold with the oldest age group (if it did, the relationship with age, described by using linear statistics, would be even stronger). The explanation for this could be in social changes that occurred during the second half of the $20^{\text {th }}$ century, like migration to cities, increasing education levels and changes in smoking habits.

Tobacco is a habit originating in cities $[45,46]$ and so elder participants in the current sample who live in villages at high elevation tend to be non-smokers. Chromosomal changes that can cause NPB and NB become more frequent with age [4]. In the current sample there were no gender differences in $\mathrm{MN}$ frequency across different age groups.

In the study of 50 healthy children from urban areas in Croatia, ages from 4-14 years, girls showed higher mean values of the mean frequency of $\mathrm{MN}$, mean frequency of nucleoplasmic bridges (NPBs), nuclear buds and the mean nuclear division index (NDI) compare to boys, but only total number of NPBs was statistically significant [5]. In the current study the mean frequency of $\mathrm{MN}$ for all subjects was $2.32 \pm 0.28$ per $1000 \mathrm{BN}$ cells which is higher value than the level obtained for the second age group. That could be due to differences in environmental factors in urban area [47]. As Regan et al. reported [23], when female-specific health dimensions are considered, females are found to accumulate more deficits than males and speculate that such opposite trends for males and females can result in no gender differences. In the current sample there were no differences in $\mathrm{MN}$ frequency between males and females for the same age group. Results of [23] suggest that aging rates approximated by the rates of changes in respective deficit indices (Dis) are not altered by gender but are specific for place of living. Similar results were obtained [28] with Italian siblings of 90 years of age and older from different parts of Italy. Large longitudinal study of aging Danish twins confirmed negative influence of sun exposure, smoking and of low BMI on facial ageing. This study indicated that high social status, low depression score and being married are associated with a younger appearance, but the strength of the associations varied between genders [24]. Basal level of MN frequency in healthy population is different in different 
nations and may vary due to characteristics and genetic origin of the sample $[4,9,10,11,13]$.

Relative to the unknown factor that independently of age, influences all these variables expect nuclear buds, we are free to suggest that it could be a lifestyle component that varies across age groups (middle age people tend to live in urban areas and lead more stressful lives, while elderly people from the current sample are 20-30 years in retirement, lead active but non-stressful lives. It is possible that in the 5th age group natural selection was the most pronounced - in childhood they were exposed to more stressful environmental factors than participants in other age groups (they survived Second World War, and scarcity of basic goods in the post-war years), and other large social changes, like massive migrations to cities, occurred during their lifetimes. Studies showed that animals exposed to stress early become more adaptive to stress [7]. Relation between lifestyle and telomere length was discussed by Lin et al. [48] suggesting several inter-related biochemical pathways: stress hormones, inflammation and oxidative stress [48]. It is possible that unique selection factors that were present in generation born in the previous century as well as cultural differences contributes to results we obtained, but more detailed study is required to test these hypotheses.

\section{References}

1. Martino-Roth MG, Viégas J, Amaral M, Oliveira L, Ferreira FLS and Erdtmann B. Evaluation of genotoxicity through micronuclei test in workers of car and battery repair garages. Genet Mol Biol 2002; 25(4):495-500.

2. Silva-Barbosa I, Pereira-Magnata S, Amaral A, Sotero G, Homero Melo C. Dose assessment by quantification of chromosome aberrations and micronuclei in peripheral blood lymphocytes from patients exposed to gamma radiation. Genet Mol Biol 2005; 28(3):452-457.

3. Diler SB, and Ergene S. Nuclear anomalies in the buccal cells of calcite factory workers. Genet Mol Biol 2010; 33(2):374--378.

4. Fenech M, Kirsch-Volders M, Natarajan AT, Surralles J, Crott JW, Parry J, Norppa H, Eastmond DA, Tucker JD, Thomas P. Molecular mechanisms of micronucleus, nucleoplasmic bridge and nuclear bud formation in mammalian and human cells. Mutagenesis 2011; 26(1):125-132.

5. Gajski G, Gerica M, Oreljanin V, Garaj-Vrhova V. Cytogenetic status of healthy children assessed with the alkaline comet assay and the cytokinesis-block micronucleus cytome assay. Mutat Res 2013; 750(1-2):55-62.

6. Dass SB, Ali SF, Heflich RH, Casciano DA. Frequency of spontaneous and induced micronuclei in the peripheral blood of aging mice. Mutat Res 1997; 381(1):105-110.

7. Bolognesi C, Lando C, Forni A, Landini E, Scarpato R, Migliore L, Bonassi S. Chromosomal damage and ageing: effect on micronuclei frequency in peripheral blood lymphocytes. Age Ageing 1999; 28(4):393-397.

8. Bonassi S, Fenech M, Lando C, Lin YP, Ceppi M, Chang WP, Holland N, Kirsch-Volders M, Zeiger E, Ban S, et al. Human micronucleus project: international database comparison for results with the cytokinesis-block micronucleus assay in human lymphocytes: I. Effect of laboratory protocol, scoring criteria, and host factors on the frequency of micronuclei. Environ Mol Mutagen 2001; 37(1):31-45.

9. Milosevic-Djordjevic O, Grujicic D, Novakovic T, Arsenijevic S, and Marinkovic D. Micronuclei and Ageing in a Sample of Yugoslavian Population. Genetica 2002; 38(2):264-267.

\section{Conclusion}

The study has demonstrated a clear relation between the frequency of micronuclei and age. Age can also be taken to explain the relations of several other studied variables with the frequency of micronuclei. Another factor that independently of age influences all examined variables except nuclear buds was proposed based on the data. According to our results $\mathrm{MN}$ frequency is related to age and unknown factor, which seems to be some aspect of socio-economic/demographic status. Further analyses are needed to determine this factor. Determining the nature of this factor could contribute to better understanding the process of aging and contributions of non-genetic factors on process of aging.

Acknowledgements: We thank all examinees that participated in the study. Special thanks to Gerontology Center Nis for selecting the participants, to Dr. Ivana Stankovic and Health centre Bela Palanka for selecting the examinees above 80 years of age, Dr. Olga Stojanovic from Clinic Brestovac and Student Policlinic Nis for excellent cooperation. Parts of this research were supported by the Ministry of Education, sciences and technology of the Republic of Serbia through Mathematical Institute SASA, Belgrade, Grant ON 174001 and Grant III41010 through Faculty of Science University of Kragujevac.

10. Garaj-Vrhovac V, Đurinec M, Kopjar N, Oreščanin V. A survey on the cytogenetic status of the Croatian general population by use of the cytokinesis-block micronucleus assay. Mutat Res 2008; 649(1-2):91-100.

11. Donmez-Altuntas H, Bitgen N. Evaluation of the genotoxicity and cytotoxicity in the general population in Turkey by use of the cytokinesis-block micronucleus cytome assay. Mutat Res 2012; 748(1-2):1-7.

12. Nefic H, Handzic I. The effect of age, sex, and lifestyle factors on micronucleus frequency in peripheral blood lymphocytes of the Bosnian population. Mutat Res 2013; 753(1):1-11.

13. Coskun M, Akın Cayır, Coskun M, Tok H. Evaluation of background DNA damage in a Turkish populationmeasured by means of the cytokinesis-block micronucleuscytome assay. Mutat Res 2013; 757(1):23-27.

14. Sato S-I, Taketomi M, Nakajima M, Kitazawa M, Shimada H, Itoh S, Igarashi M, Higashikuni N, Sutou S, Sasaki YF. Effect of aging on spontaneous micronucleus frequencies in peripheral blood of nine mouse strains: the results of the 7th collaborative study organized by CSGMT/JEMS MMS. Mutat Res 1995; 338(1-6):51-57.

15. Kirsch-Volders M, Plas G, Elhajouji A, Lukamowicz M, Gonzalez L, Vande Loock K, Decordier I. The in vitro MN assay in 2011: origin and fate, biological significance, protocols, high throughput methodologies and toxicological relevance. Arch Toxicol 2011; 85(8):873-899.

16. Fenech M, Neville S, Rinaldi J. Sex is an important variable affecting spontaneous micronucleus frequency in cytokinesisblocked lymphocytes. Mutat Res 1994; 313(2-3):203-207.

17. Kažimirova $M$, Barančokova $M$, Krajčovičova-Kudlačkova $M$, Volkovová K, Staruchová M, Valachovicová M, Pauková V, Blazícek P, Wsólová L, Dusinská M. The relationship between micronuclei in human lymphocytes and selected micronutrients in vegetarians and non-vegetarians. Mutat Res 2006; 611(1-2):64-70. 
18. Dahlström Heuser V, de Andrade VM, Peres A, de Macedo Braga LMG, Chies JAB. Influence of age and sex on the spontaneous DNA damage detected by Micronucleus test and Comet assay in mice peripheral blood cells. Cell Biol Int 2008; 32(10):1223-1229.

19. Bhilwade HN, Jayakumar S, Chaubey RC. Age-dependent changes in spontaneous frequency of micronucleated erythrocytes in bone marrow and DNA damage in peripheral blood of Swiss mice. Mutat Res 2014; 770:80-84.

20. Mayer PJ, Lange CS, Bradley MO, Nichols WW. Gender differences in age-related decline in DNA double-strand break damage and repair in lymphocytes. Ann Hum Biol 1989; 18(5):405-415. Published online: 09 Jul 2009.http://dx.doi.org/ 10.1080/03014469100001702.

21. Lakshmi NK, Tiwari R, Bhargava SC and Ahuja YR. Investigations on DNA damage and frequency of micronuclei in occupational exposure to electromagnetic fields (EMFs) emitted from video display terminals (VDTs) Genet Mol Biol 2010; 33(1):154-158.

22. Martin-Ruiz C, Jagger C, Kingston A, Collerton J, Catt M, Davies K, Dunn M, Hilkens C, Keavney B, Pearce SH, den Elzen WP, Talbot D, Wiley L, Bond J, Mathers JC, Eccles MP, Robinson L, James O, Kirkwood TB, von Zglinicki T. Assessment of a large panel of candidate biomarkers of ageing in the Newcastle 85+ study. Mech Ageing Devl 2011; 32(10):496-502.

23. Regan JC, Partridge L. Gender and longevity: Why do men die earlier than women? Comparative and experimental evidence. Best Pract Res Clin Endocrinol Metab 2013; 27(4):467-479.

24. Rexbye H, Petersen I, Johansen M, Klitkou L, Jeune B, Christensen $\mathrm{K}$. Influence of environmental factors on facial ageing. Age Ageing 2006; 35(2):110-115

25. Johnson TE. Recent results: Biomarkers of aging. Exp Gerontol 2006; 41(12):1243-1246

26. Harrisa SE, Martin-Ruizc C, von Zglinickic T, Starrd JM, Deary IJ. Telomere length and aging biomarkers in 70-year-olds: the Lothian Birth Cohort 1936. Neurobiol Aging 2012; 33(7):1486.e3-8.

27. Steves CJ, Spector TD, Jackson SHD. Ageing, genes, environment and epigenetics: what twin studies tell us now, and in the future. Age Ageing 2012; 41(5):581-586.

28. Cevenini E, Cotichini R, Stazi MA, Toccaceli V, Scurti M, Mari V, Berardelli M, Passarino G, Jeune B, Franceschi C. How to classify the oldest old according to their health status: A study on 1160 subjects belonging to $55290+$ Italian sib-ships characterized by familial longevity recruited within the GEHA EU Project. Mech Ageing Dev 2013; 134(11-12):560-569.

29. Torrão RC, Bennett SJ, Brown JE, Griffiths HR. Does metabolic reprogramming under pinage-associated changes in T-cell phenotype and function? Free Radic Biol Med 2014; 71:26-35

30. Klein BEK, Knudtson MD, Lee KE, Klein R. Parents' attained age and biomarkers of aging in their children. Arch Gerontol Geriat 2009; 49(2):284-8.

31. Fyhrquist F, Saijonmaa O. Telomere length and cardiovascular aging. Ann Med 2012; 44 Suppl 1:S138-42.

32. Radak Z, Koltai E, Taylor AW, Higuchi M, Kumagai S, Ohno H, Goto S, Boldogh I. Redox-regulating sirtuins in aging, caloric restriction, and exercise. Free Radic Biol Med 2013 ; 58:87-97.
33. Liochev SI. Reactive oxygen species and the free radical theory of aging. Free Radic Biol Med 2013; 60:1-4.

34. Witczaka M, Ferenca T, Gulczynskab E, Nowakowskac D, Łopaczynskaja D, Wilczynskic J. Elevated frequencies of micronuclei in pregnant women with type 1diabetes mellitus and in their newborns. Mutat Res 2014; 763:12-17.

35. Moore LG. Human Genetic Adaptation to High Altitude. High Alt Med Biol 2004; 2(2):257-279.

36. Storz FJ. Perspectives. Genes for High Altitudes. Science 2010; 329(5987):40-41.

37. van Patot MCT, and Gassman M. Hypoxia: Adapting to high altitude by mutating EPAS-1, the gene encoding HIF- $2 \alpha$. High Alt Med Biol 2011; 12(2):157-167.

38. Lorenzo RF, Huff C, Myllymäki M, Olenchock B, Swierczek S, Tashi T, Gordeuk V, Wuren T, Ri-Li G, McClain AD, Khan MT, Koul AP, Guchhait P, Salama EM, Xing J, Semenza LG, Liberzon E, Wilson A, Simonson S.T, Jorde B.L, Kaelin Jr GW, Koivunen P, Prchal TJ. A genetic mechanism for Tibetan highaltitude adaptation. Nat Genetics 2014; 46(9):951-956.

39. Fenech M. Cytokinesis-block micronucleus cytome assay. Nat Protoc 2007; 2(5):1084-1104.

40. Starr JM, Shiels PG, Harris SE, Pattie A, Pearce MS, Relton CL, Deary IJ. Oxidative stress, telomere length and biomarkers of physical aging in a cohort aged 79 years from the 1932 Scottish Mental Survey. Mech Ageing Dev 2008; 129(12):745-751.

41. Mohammed AH, Henriksson BG, Soderstrom S, Ebendal T, Olsson T, Seckl JR. Environmental influences on the central nervous system and their implications for the aging rat. Behav Brain Res 1993; 57(2):183-191.

42. Jonesa KH, Yorkb TP, Jackson-Cooka C. Mechanisms leading to the formation of micronuclei containing sex chromosomes differ with age. Mutat Res 2012; 747(2):207-217.

43. Babizhayev MA, Savel'yeva EL, Moskvina SN, Yegorov YE. Telomere length is a biomarker of cumulative oxidative stress, biologic age, and an independent predictor of survival and therapeutic treatment requirement associated with smoking behavior. Am J Ther 2011; 18(6):209-226.

44. Szklarska A, and Rogucka E. An assessment of biological age of males in Poland. Ann Hum Biol2001; 28(1):30-37.

45. Liu L, Edland S, Myers MG, Hofstetter CR, Al-Delaimy WK Smoking prevalence in urban and rural populations: findings from California between 2001 and 2012. Am J Drug Alcohol Abuse 2016; 42(2):152-161.

46. Liu Y, Gao J, Shou J, Xia H, Shen Y, Zhu S, Pan Z. The Prevalence of Cigarette Smoking Among Rural-to-Urban Migrants in China: A Systematic Review and Meta-Analysis. Subst Use Misuse 2016; 51(2):206-215.

47. Pedersen M, Wichmann J, Autrup H, Dang DA, Decordier I, Hvidberg M, Bossi R, Jakobsen J, Loft S, Knudsen LE. Increased micronuclei and bulky DNA adducts in cord blood after maternal exposures to traffic-related air pollution. Environ Res 2009; 109(8):1012-1020.

48. Lin J, Epel E, Blackburn E. Telomeres and lifestyle factors: roles in cellular aging. Mutat Res 2012; 730(1-2):85-89. 